\title{
Mapping Tsunami Vulnerability Area for Bacan Sub-District and Its Surroundings - North Maluku Province
}

\author{
Mohammad Ridwan Lessy ${ }^{1 *}$, and Mesrawaty Sabar $^{2}$ \\ ${ }^{1}$ Marine Science Department, Universitas Khairun - Ternate, 97716, Indonesia \\ ${ }^{2}$ Marine Resources Management Department, Universitas Khairun - Ternate, 97716, Indonesia
}

\begin{abstract}
This research aims to explore tsunami-prone areas in the Bacan and South Bacan districts of South Halmahera Regency. The findings of this research are planned to assist all stakeholders, particularly in developing disaster risk assessment sheets. To estimate the tsunami hazard map, the susceptibility of the elevation, slope, river distance, and coastal distance was collected. Overlaying thematic maps were used assisted by GIS software. The result shows that the low and very low tsunami vulnerability areas were safe from tsunami inundation predominate in the Eastern part and Northern part of the study area while the area designated as very vulnerable covered 157,10 hectares. These locations may have sustained the most damage from a tsunami catastrophe due to their proximity to the sea, low terrain and slope, and dense population. In consideration of the tsunami disasters in Aceh, we anticipate that tsunami risk maps will support in the initiation of humanitarian and development activities in North Maluku Province.
\end{abstract}

Keywords: Tsunami vulnerability; North Maluku; GIS

\section{Introduction}

The tsunami disaster can cause negative impact, both property and life [1], and have an impact on the environment and people's lives [2]; health [3]. The tsunami disaster cannot be avoided but the consequences caused by the tsunami can be minimized by taking preventive programs.

The eastern part of Indonesia is recorded to have a high risk of a tsunami. This is because tectonically this area is influenced by the Philippine Plate Subduction in the north to the east, the Sorong and Sula Faults in the south, the East Maluku Sea Thrust, and the West Maluku Thrust in the west [4]. According to [5] about $67 \%$ of tsunamis in Indonesia occurred in eastern Indonesia which were spread evenly from Sulawesi to Papua and from Timor to the Sangihe Talaud islands where during the period between 1600 and 2004 there were approximately 109 tsunamis in Eastern Indonesia.

Currently, the North Maluku region, including South Halmahera Regency, is constantly being hit by earthquakes. According to BMKG data, more than 500 earthquakes have occurred in this area with a magnitude scale varying from $3.0-6.0$ on the Richter Scale. Even though the earthquake had not yet caused a tsunami, it caused people to panic and scatter out of their homes. This shows that there is no tsunami risk assessment that has been prepared at the village level. In this condition, the role of all elements of society and stakeholders is needed in an effort to increase awareness of disasters before, during and after disasters occur.

Indeed, tsunami studies in the northern Maluku region are still very limited. Some that have been carried out, for example, a tsunami hazard study in the North Maluku region has been carried out by [6] on Mapping of Tsunami Vulnerability and Coastline Changes in Small Islands (Case Study: Small Volcanic Island of Ternate) and [7] on mapping tsunami disaster risk in coastal areas of Weda Tengah sub-district, Central Halmahera Regency. Another research conducted by [8] about Marine Geological Hazard in Northern Part of Obi Island, Molucca found that the research area is an area that has experienced a tsunami disaster, the closest to the research site is the tsunami around Halmahera in 1994 caused by an earthquake with a magnitude of $6.8 \mathrm{Mw}$, water level (tsunami run-up) reaches $3 \mathrm{~m}$ in Obi Island.

Vulnerability of tsunami mapping, in accordance with the investigated area, should be done using a multicriteria approach. To develop a tsunami vulnerability map, spatial analytic techniques are required. Tsunami risk levels are geographically visualized using Geographic Information Systems (GIS). Merging and overlaying procedures are two GIS tools that can be used. The idea behind this strategy is to blend multiple different weights.

Therefore, this study aims to map tsunami-prone areas in Bacan District and South Bacan District, South Halmahera Regency. The results of this study are

\footnotetext{
*Corresponding author : mrlessy8375@gmail.com
} 
expected to assist all stakeholders, especially the local government of South Halmahera Regency and North Maluku Province in the context of preparing disaster risk assessment documents.

\section{Materials and Methods}

\subsection{Study sites}

This study focuses on Labuha village and seven villages such as Amasing Kota, Amasing Kota Barat, Amasing Kota Utara, Tomori, Mandaong, Tembal, and Kupal (Fig. 1). Those areas are chosen due to several reasons. First, Labuha is the capital city of South Halmahera Regency where all the human and development activities are centralized in this area. Second, those areas are coastal villages where human settlements are built. Third, the areas are vulnerable to earthquakes and tsunami.

Another reason is the population number in study areas. Statistical data in 2021 shows that the total population in the study areas is 27,829 people which is 14,108 male and 13,721 female. Labuha village has a high population number 7,249 people among other villages and the population density in Labuha villages reaches 3000 people $/ \mathrm{km} 2$.

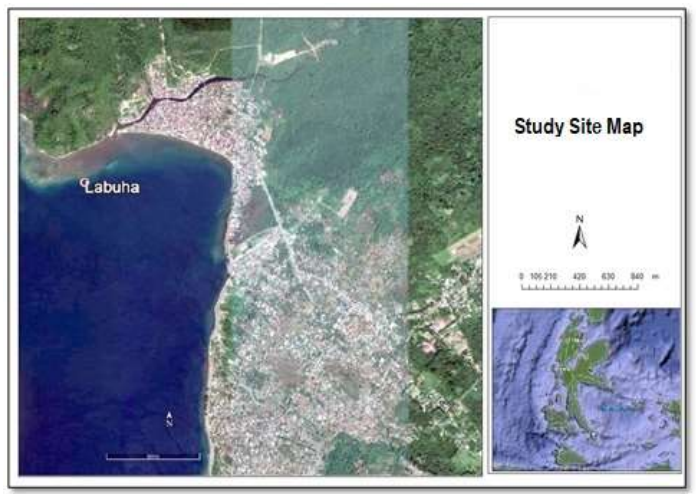

Fig. 1. Study site

\subsection{Data Collections and Analysis}

This research requires the support of adequate data and information as input with procedures for collecting data and information with appropriate methods, as well as the processing and analysing data and information using appropriate analytical techniques. The data collected in this study include primary data and secondary data. Primary data involves the existing condition of the study location including the topography of the study site, shoreline profile, location of the river, and public perception of the earthquake and tsunami disaster. While the secondary data includes: population density data, earthquake disaster events, and other data that support this research. Therefore, the proposed research methodology will be a combination of methods in the field, which will include among others: fieldwork (survey/observation, assessment and data, and information collection), map digitization, and tsunami hazard analysis.

The coastline data was obtained from the $w w w$. Tanahair.indonesia.go.id with a scale of 1:50,000. The elevation and slope were obtained from the GDEM (Global Digital Elevation Model) ASTER (The Advanced Spaceborne Thermal Emission and Reflection Radiometer) image processing which was downloaded at https://earthexplorer.usgs.gov/. As reported by [9] that SRTM DEM can bu used to evaluate natural hazards including tsunami. The distance from the shoreline was created in a polyline file for buffering the distance from the shoreline to the Land In addition, river data was obtained by digitizing from Google Earth Image 2017, and settlement data were obtained by digitizing from Digital Globe Image 2015. To create thematics maps assisted with ArcGIS 10.4 software [10][11].

Table 1. Score and Weight of each Parameters

\begin{tabular}{|c|c|c|c|}
\hline Parameters & Class & Score & Weight \\
\hline \multirow{5}{*}{$\begin{array}{l}\text { Distance from } \\
\text { coastline }(\mathrm{m})\end{array}$} & $0-500 \mathrm{~m}$ & 5 & \multirow{5}{*}{30} \\
\hline & $501-1000 \mathrm{~m}$ & 4 & \\
\hline & $1001-1500 \mathrm{~m}$ & 3 & \\
\hline & $1501-3000 \mathrm{~m}$ & 2 & \\
\hline & $>3000 \mathrm{~m}$ & 1 & \\
\hline \multirow{5}{*}{ Elevation (m) } & $<10 \mathrm{~m}$ & 5 & \multirow{5}{*}{30} \\
\hline & $11-25 \mathrm{~m}$ & 4 & \\
\hline & $26-50 \mathrm{~m}$ & 3 & \\
\hline & $51-100 \mathrm{~m}$ & 2 & \\
\hline & $>100 \mathrm{~m}$ & 1 & \\
\hline \multirow{5}{*}{ Slope $(\%)$} & $0-2 \%$ & 5 & \multirow{5}{*}{25} \\
\hline & $3-5 \%$ & 4 & \\
\hline & $6-15 \%$ & 3 & \\
\hline & $16-40 \%$ & 2 & \\
\hline & $>40 \%$ & 1 & \\
\hline \multirow{5}{*}{$\begin{array}{l}\text { Distance from river } \\
\text { (m) }\end{array}$} & $0-100 m$ & 5 & \multirow{5}{*}{15} \\
\hline & $101-200 \mathrm{~m}$ & 4 & \\
\hline & $201-300 \mathrm{~m}$ & 3 & \\
\hline & $301-500 \mathrm{~m}$ & 2 & \\
\hline & $>500 \mathrm{~m}$ & 1 & \\
\hline
\end{tabular}

The susceptibility of the elevation, slope, river distance, and coastal distance was divided into five categories. This classification method identifies the best class breaks to group similar values, maximize the differences between classes, minimize value differences between data within the same class, and emphasize the differences between the reclassified classes by selecting the class breaks that best group similar values.

To estimate the tsunami hazard level (Fig. 2), overlay techniques or overlaying thematic maps were used. Then, the scoring and weighting methods were applied to calculate the hazard score. The scores and 
weights for each parameter can be seen in Table 1 . Mathematically, the scoring and weighting are carried out using the following formula;

$X=\sum_{I=1}^{n}(W i x X i)$

where:

$\mathrm{X}=$ Hazard Value

$\mathrm{Wi}=$ Weight of Parameter $\mathrm{i}$

$\mathrm{Xi}=$ The criterion score of Parameter $\mathrm{i}$

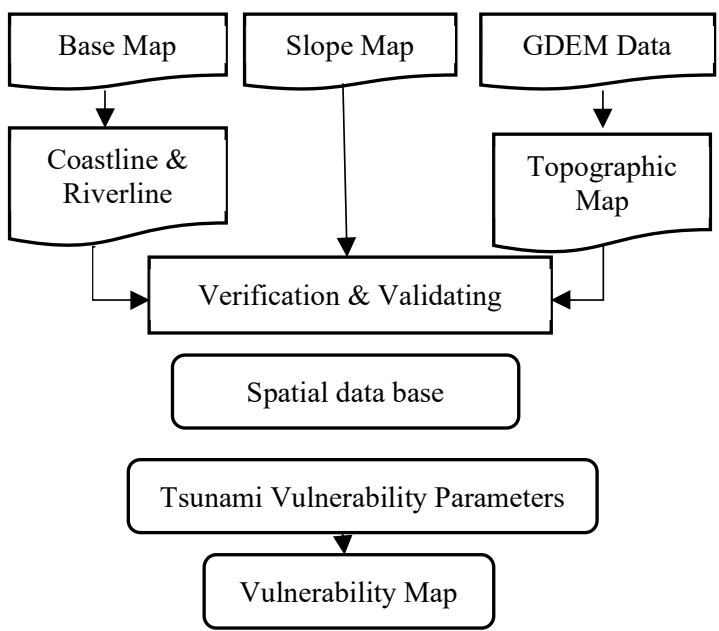

Fig. 2. Flowchart of Data Processing and Analysis

\section{Result and Discuss}

\subsection{Elevation and Slope on Study Areas}

As a part of the Geomorphologic features, elevation and slope have a significant role in regulating tsunami runup in a given area [13]. Scientifically, elevation means the shape of the earth's surface elevation generally presents surface relief, three-dimensional models, and the identification of land types.

Elevated landforms have been found to be less vulnerable to tsunamis than low-lying landforms that lack resilience. The coastal plain, waterbody, and plateau are the geomorphology classes in this study region. The coastal lowlands are given the most weight because of their significant vulnerability to tsunamis.

Figure 3 showed the tsunami susceptibility to land elevation (topography) is divided into 5 classes namely, very high (1-10 m), high (10-25 m), medium (25 - 50 $\mathrm{m})$, low $(50-100 \mathrm{~m})$, and very low $(>100 \mathrm{~m})$. According to [14], the lower the land elevation of an area, the greater the level of vulnerability to tsunami hazards.

The results of the elevation map analysis in the study region suggest that most of Bacan District's coastal areas are lowlands with an altitude of $0-10 \mathrm{~m}$, while certain localities, such as Amasing Kota Utara Village and Amasing Kota Village, have an elevation of 11-50 m. Meanwhile, the geography of the South Bacan District is similar to that of the Bacan District, with elevations ranging from 0 to 10 meters, except in Tembal and Kupal Villages, where elevations range from 11 to 50 meters. The coastline area in the research location has a very high level of sensitivity to tsunami waves, as can be observed from these data. Generally, areas with higher elevation are least affected by a tsunami, whereas those areas with lower elevation are seriously affected.

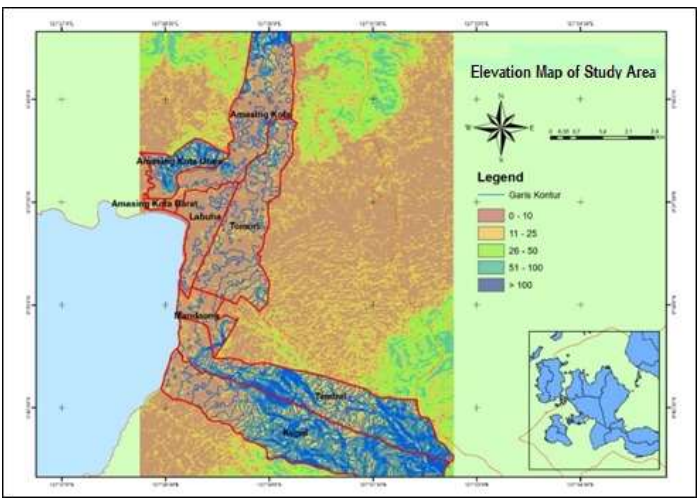

Fig. 3. Land Elevation Map of Study Area

The slope is a measure of the distance between the vertical and horizontal planes, and it is usually stated in percent $(\%)$ or degrees (o), however in this study, the unit of slope is percent. Tsunami run-up can be severe in regions with a relatively flat topographic grade, because the tsunami can easily flow onto flat lands, but hills adjoining the beach can hold or divert it [10]. The lesser the effect of tsunami wave height, the steeper the slope [15].

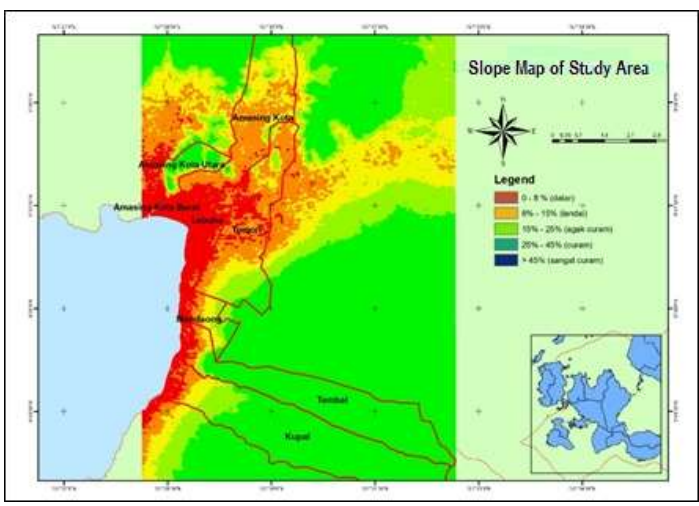

Fig. 4. Slope Map of Study Area

The analysis result shows that in Bacan and South Bacan sub-district, the majority of the research coastal regions are controlled by flat to mild slopes (2 -15\%). Meanwhile, the areas of Tembal Village and Kupal Village were dominated by areas with a very steep category $(15-25 \%)$. The coastal areas of Bacan and South Bacan sub-district, which are dominated by flat slopes, have a very high level of sensitivity to tsunami waves from the point of view of the slope, as can be observed from this data. The slope of study area was shown in fig. 4

According to [16], on a low land location with a relatively level slope, the impact of a tsunami can be devastating. This is due to the fact that runoff can easily flow without being significantly disrupted by topography changes. 


\subsection{Distance of Study Area from Coastline and River}

The land along the shore that has proportional width to the shape and physical condition of the beach, at least $100 \mathrm{~m}$ from the highest tidal point towards the land, is referred to as distance from the shoreline or coastal border [17]. In this study, the coastal border was drawn at a distance of at least 500 meters from the land. It is well known that an area 500 meters from the coastline has a very high level of vulnerability, and an area more than 3000 meters away has a very low level of vulnerability.

A distance from the shoreline map showing the most vulnerable areas to tsunami impact (red areas) had a distance of $500 \mathrm{~m}$ (Fig.5). [18] stated that the greater the vulnerability of a region to tsunami risk, the closer it is to the sea.

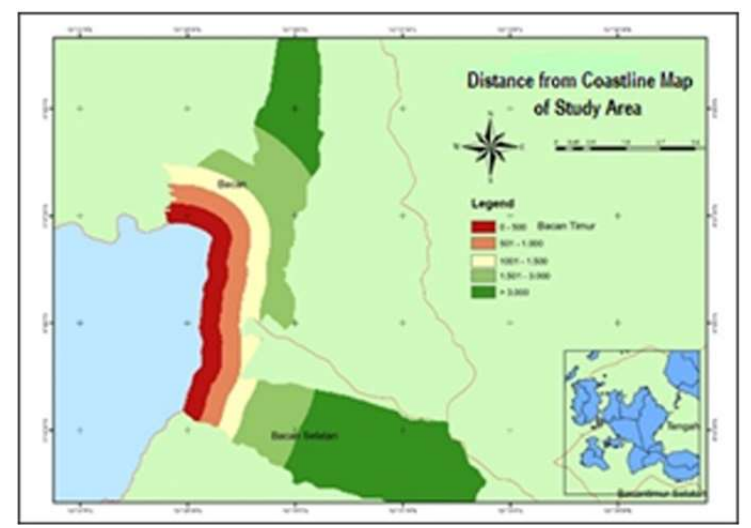

Fig. 5. Distance from Coastline Map

Observations in the field revealed that settlements particularly vulnerable to tsunamis were found in all villages particularly close to the coast. In general, the most important facilities in this region were located within 100-200 meters of the shoreline. As a result, the settlements in the area were designated as highly vulnerable to tsunami waves. As a result, the best spatial planning is required to reduce the tsunami risk.

In addition to distance from the river, distance from the coastline is a critical element in assessing tsunami danger. A river bank should be at least 100 meters broad on both sides of the river. In general, a tsunami traveling across a river would inflict substantial damage. When a tsunami travels through a small region, such as a river, the velocity and water level rise due to the fact that the same water mass flow must pass through the narrow slit simultaneously [19]. As a result, the tsunami safe zone should be located far away from the river.

Figure 6 depicts a map of the distance between the river and the location of the location of the river. There are two significant rivers in the area, the Amasing River in Bacan sub-district and the Mandaong River in South Bacan sub-district, both of which flow through the district. A very high degree of susceptibility exists when the settlements are fewer than 100 meters distant from river borders, and a very low level of vulnerability exists when settlements are more than 500 meters apart from river borders.
Conforming to [20], this situation may result in a tsunami discharge that travels farther inland in places next to the river than in areas not adjacent to the river. As a result, the location of highly populated residential areas and other significant economic areas should be built at a relatively far distance from the river which is about $>500 \mathrm{~m}$ from the river

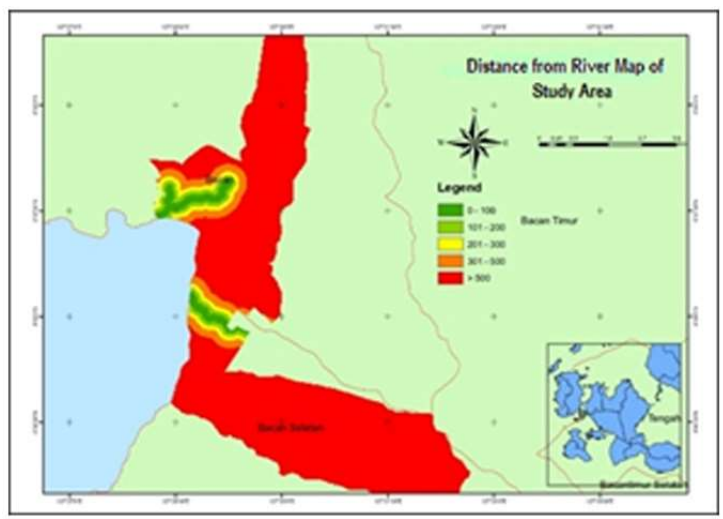

Fig. 6. Distance from River Map

\subsection{Tsunami Vulnerability Map}

Weighted overlay is a method for integrating disparate and different inputs by applying a common measuring scale to them. By detecting and evaluating regions according to criteria, weighted overlay analysis enables the user to integrate and display many distinct kinds of information in order to assess several variables simultaneously $[21][10$ Guntur]. Furthermore, the susceptibility region owing to tsunami danger was defined using cell-based modelling in spatial analysis.

The degree of tsunami sensitivity in study area was classified into five categories depending on the region's susceptibility to tsunamis. There were five categorization levels: very low, low, medium, high, and very high. Figure 7 showed the tsunami vulnerability map on study location.

Tsunami waves have the least impact when they hit places that are far away from the sea and the greatest impact when they strike regions that are near to the sea. The tsunami's height diminishes as the distance between the shore and the land increases [22]. Pangandaran coastal area, for example, had a tsunami with a height ranging from 1.6-7.6 meters [17]. Areas with a high level of threat to tsunamis are areas with a high level of risk and vulnerability to tsunamis, and the reverse is true. 


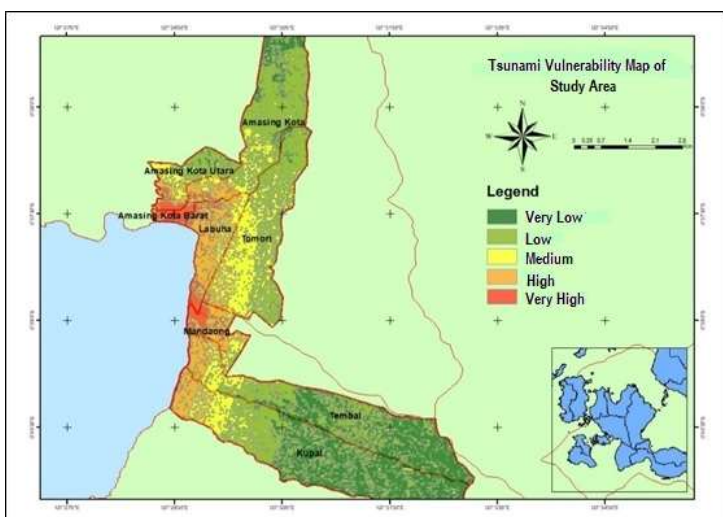

Fig. 7. Tsunami Vulnerability Map

According to the result of the study, the low and very low tsunami vulnerability areas were safe from tsunami inundation predominate in the Eastern part and Northern part of the study area. This area was characterized by high topography, large land slope, distance from coastal and river. This area involdes such as the northern part of Amasing Kota Utara Village, Amasing Kota village. And also, Eastern parts of Tomori Village, Tembal Village, and Kupal village. Those are had elevation more than $25 \mathrm{~m}$.

While the areas that has high and very high susceptibility, on the other hand, are mostly found near the shore or immediately next to the coast, as well as areas close to river flows in the Bacan and South Bacan sub-districts. In addition, Those areas directly adjacent to the sea at the zone of $0-1000 \mathrm{~m}$ from the shoreline and $0-100 \mathrm{~m}$ of river bank. The shape of the coast also affects the high tsunami risk. According to [23] that the high tsunami risk zone is represented by regions along the coast to the east of the study area, especially in the bay-shaped areas, which are particularly vulnerable to tsunamis.

The results of the tsunami area estimate per category. The research site was found to be dominated by regions classified as low or very low tsunami risks, accounting for 35.0 percent and 31.65 percent, or 1411.59 and 1274,6 hectares, respectively. Meanwhile, regions classified as high or very high susceptibility are 11.56 percent and 17.84 percent, or 465.75 ha and 157.10 ha, respectively. The calculation result showed in table 2.

Table 2. Tsunami vulnerable area

\begin{tabular}{|l|r|r|}
\hline \multicolumn{1}{|c|}{ Categories } & \multicolumn{1}{c|}{ Area (ha) } & \multicolumn{1}{c|}{ \% } \\
\hline Very low & 1274,60 & 31,65 \\
\hline Low & 1411,59 & 35,05 \\
\hline Medium & 718,68 & 3,90 \\
\hline High & 465,75 & 11,56 \\
\hline Very High & 157,10 & 17,84 \\
\hline Total & $\mathbf{4 0 2 7 , 7 3}$ & $\mathbf{1 0 0}$ \\
\hline
\end{tabular}

\subsection{Discussion}

The movement of tsunami waves are different from ordinary sea waves. tsunami waves have more unique characteristics, because the wave shape extends throughout the water column from the bottom to the top. sea level. The direction in which a tsunami wave propagates has an effect on its speed and height when it reaches the shore. Areas perpendicular to a tsunami wave's direction may be significantly impacted by the wave's energy concentration [24].

Tsunami is a natural catastrophe that has always posed a danger to those who live along the shore. Although it is uncommon, the tsunami catastrophe is a force to be reckoned with due to its immense destructive potential. While the finding indicates that areas of extreme vulnerability were relatively small in comparison to the overall research area, the places were highly inhabited, infrastructure development was concentrated along the shore, and the terrain was relatively flat $(1-10 \mathrm{~m})$. As a result, the area is particularly vulnerable to tsunami damage. Based on the results of field investigations, important infrastructure incorporated in coastal areas such as government offices, schools, bridges, markets, houses of worship, and gas stations (Fig.8). Therefore, it was essential to develop methods and regulations aimed at minimizing damage and fatalities caused by tsunami impact.

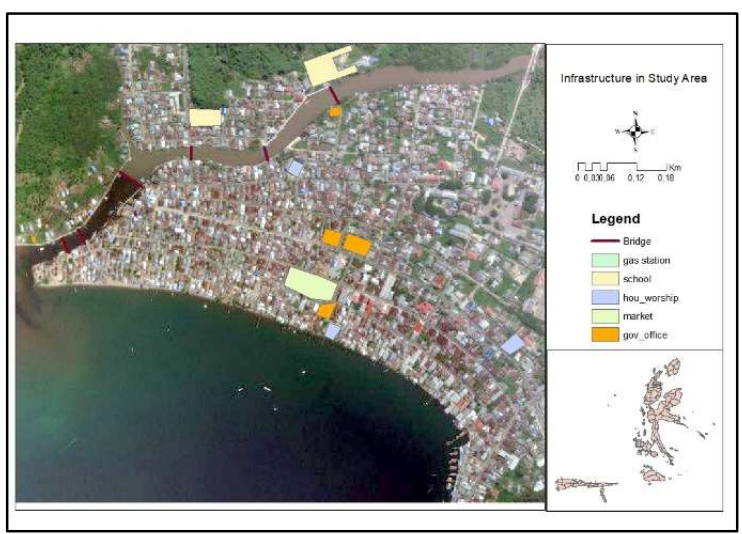

Fig. 8. Infrastructure in Tsunami Vulnerability Area

\section{Conclusion}

Through the use of spatial analysis such as topographic operations, proximity calculation, buffer construction, raster reclassification, and intersection operations, GISbased studies may be beneficial in a broad variety of disaster assessment applications including Tsunami vulnerability. The susceptibility to tsunamis varied according to slope, elevation, land use, distance from the shore, and distance from the river in the studied regions. The area designated as very vulnerable covered 157,10 hectares. These locations may have sustained the most damage from a tsunami catastrophe due to their proximity to the sea, low terrain and slope, and dense population. In consideration of the tsunami disasters in Aceh, we anticipate that tsunami risk maps will support 
in the initiation of humanitarian and development activities in North Maluku Province.

\section{References}

[1] P. Subardjo and R. Ario, "Uji Kerawanan Terhadap Tsunami Dengan Sistem Informasi Geografis (SIG) Di Pesisir Kecamatan Kretek, Kabupaten Bantul, Yogyakarta," J. Kelaut. Trop., vol. 18, no. 2, pp. 82-97, (2016), doi: 10.14710/jkt.v18i2.519.

[2] M. Z. Asmawi and A. N. Ibrahim, "The Impacts of Tsunami on the Well-Being of the Affected Community in Kuala Muda, Kedah, Malaysia," J. Clean Energy Technol., vol. 1, no. 3, pp. 246250, (2014), doi: 10.7763/jocet.2013.v1.56.

[3] M. Carballo, S. Daita, and M. Hernandez, "Impact of the Tsunami on healthcare systems," J. R. Soc. Med., vol. 98, no. 9, pp. 390-395, (2005), doi: 10.1258/jrsm.98.9.390.

[4] C. Sulaeman and A. Cipta, "Model intensitas gempa bumi di Maluku Utara Earthquake Intensity Model in North Maluku," J. Lingkung. dan Bencana Geol., vol. 3, no. 2, pp. 79-88, (2012).

[5] L. HAMZAH, N. T. PUSPITO, and F. IMAMURA, "Tsunami Catalog and Zones in Indonesia.," J. Nat. Disaster Sci., vol. 22, no. 1, pp. 25-43, (2000), doi: 10.2328/jnds.22.25.

[6] K. Evrita, M. A. Marfai, N. Khakim, and E. T. W. Mei, "Tsunami susceptibility mapping in the coastal area of Ternate Island," (2014).

[7] M. R. Lessy, N. Wahiddin, R. M. Abdullah, and J. Bemba, "Pemetaan Risiko Bencana Tsunami di Wilayah Pesisir Kecamatan Weda Tengah, Kabupaten Halmahera Tengah, Maluku Utara," (2018).

[8] N. Y. Geurhaneu, F. Budi, and G. Latuputty, "Marine Geological Hazard in Northern Part of Obi Island, Molucca," vol. 14, no. 1, pp. 23-36, (2016).

[9] L. Yang, X. Meng, and X. Zhang, "SRTM DEM and its application advances," Int. J. Remote Sens., vol. 32, no. 14, pp. 3875-3896, (2011), doi: $10.1080 / 01431161003786016$.

[10] T. P. T. Sinaga, A. Nugroho, Y. W. Lee, and Y. Suh, "GIS mapping of tsunami vulnerability: Case study of the Jembrana regency in Bali, Indonesia," KSCE J. Civ. Eng., vol. 15, no. 3, pp. 537-543, (2011), doi: 10.1007/s12205-0110741-8.

[11] A. B. Sambah and F. Miura, "Spatial data analysis and remote sensing for observing tsunami-inundated areas," Int. J. Remote Sens., vol. 37, no. 9, pp. 2047-2065, (2016), doi: 10.1080/01431161.2015.1136450.

[12] F. Hadi and D. Astrid, "Aplikasi SIG Untuk Pemetaan Zona Keterpaparan Permukiman Terhadap Tsunami Studi Kasus : Kota Pariaman , Sumatera Barat," Semin. Nas. Geomatika, pp. 317-324, (2017)

[13] R. S. Ajin, M. K. Jacob, and P. G. Vinod,
"Tsunami vulnerability mapping using remote sensing and GIS techniques: A case study of Kollam District, Kerala, India," Iran. J. Earth Sci., vol. 6, no. 1, pp. 43-50, (2014).

[14] O. Oktariadi, "Penentuan Peringkat Bahaya Tsunami dengan Metode Analytical Hierarchy Process (Studi kasus: Wilayah Pesisir Kabupaten Sukabumi)," Indones. J. Geosci., vol. 4, no. 2, pp. 103-116, (2009), doi: 10.17014/ijog.vol4no2.20093.

[15] E. Sengaji and B. Nababan, "Pemetaan Tingkat Risiko Tsunami di Kabupaten Sikka, Nusa Tenggara Timur," E-Jurnal Ilmu dan Teknol. Kelaut. Trop., vol. 1, no. 1, pp. 48-61, (2009).

[16] Eddy, "GIS in disaster management: a case study of tsunami risk mapping in Bali, Indonesia," James Cook University, (2006).

[17] M. M. Faiqoh,;Gaol, J.L; Ling, "VULNERABILITY LEVEL MAP OF TSUNAMI DISASTER IN PANGANDARAN BEACH, WEST JAVA," Int. J. Remote Sens. Earth Sci., vol. 10, no. 2, pp. 90-103, (2013).

[18] A. P. Putra, "Mapping Tsunami Vulnerability for Mataram City in Lombok Island - Indonesia: a Physical and Socioeconomic Assessment," $J$. Pengemb. Kota, vol. 3, no. 1, p. 60, (2015), doi: 10.14710/jpk.3.1.60-79.

[19] F. Lovholt, G. Pedersen, and S. Glimsdal, "Coupling of Dispersive Tsunami Propagation and Shallow Water Coastal Response," Open Oceanogr. J., vol. 4, no. 1, pp. 71-82, (2014), doi: 10.2174/1874252101004010071.

[20] B. Mardiyanto, B. Rochaddi, and M. Helmi, "Kajian Kerentanan Tsunami Menggunakan Metode Sistem Informasi Geografi," J. Mar. Res., vol. 2, no. 1, pp. 103-111, (2013).

[21] Guntur, A. B. Sambah, F. Miura, Fuad, and D. M. Arisandi, "Assessing tsunami vulnerability areas using satellite imagery and weighted cellbased analysis," Int. J. GEOMATE, vol. 12, no. 34, pp. 115-122, (2017), doi: 10.21660/2017.34.2726.

[22] S. H. Rahmawan, I. Gunawan, A. . Musa, and A. Muhammad, "Study of potential tsunami hazard in South Java," J. Meteorol. (in Indones., vol. 4, no. 1, pp. 6-10, (2012).

[23] M. A. Mustafa and Y. Yudhicara, "Karakteristik Pantai Dan Resiko Tsunami Di Kawasan Pantai Selatan Yogyakarta," J. Geol. Kelaut., vol. 5, no. 3, pp. 159-167, (2016), doi: 10.32693/jgk.5.3.2007.143.

[24] M. Umitsu, C. Tanavud, and B. Patanakanog, "Effects of landforms on tsunami flow in the plains of Banda Aceh, Indonesia, and Nam Khem, Thailand," Mar. Geol., vol. 242, no. 13, pp. 141-153, (2007), doi: 10.1016/j.margeo.2006.10.030. 